\title{
Evaluation of soybean breeding lineages to new sources of root-knot nematode resistance
}

\section{Avaliação de linhagens de melhoramento de soja para novas fontes de resistência a nematóides de galhas}

\author{
Osvaldo Toshiyuki Hamawaki ${ }^{1}$, Raphael Lemes Hamawaki ${ }^{2}$, Ana Paula Oliveira Nogueira ${ }^{3}$, \\ Jacqueline Siqueira Glasenapp ${ }^{1 *} \mathbb{D}$, Cristiane Divina Lemes Hamawaki ${ }^{4} \mathbb{D}$, Carolina Oliveira da Silva ${ }^{1}$
}

\author{
'Universidade Federal de Uberlândia/UFU, Instituto de Ciências Agrárias, Uberlândia, MG, Brasil \\ ${ }^{2}$ Southern Illinois University Carbondale, Carbondale, IL, USA \\ 3Universidade Federal de Uberlândia/UFU, Instituto de Genética e Bioquímica, Uberlândia, MG, Brasil \\ ${ }^{4}$ Instituto Master de Ensino Presidente Antônio Carlos/IMEPAC, Araguari, MG, Brasil \\ Corresponding Author: siqueiragaia@gmail.com \\ Received in April 15, 2019 and approved in June 10, 2019
}

\begin{abstract}
In Brazil, as the soybean crop expands the losses caused by nematodes as well as its incidence in producing areas have increased. Therefore, this work aimed to develop a non-genetically modified soybean which combines desirable traits as the root-knot nematode resistance, early-maturity, high seed yielding, and high oil and protein contents. Consequently, seeds (F2) derived from the doublecrossing between (Guarani x Sambaiba) x (M Soy 6101 x Conquista) were bulked to grow the F3 generation. Following generations were advanced by the SSD method of breeding until F6. Thus, plants showing superior characteristics were planted separately to perform progeny tests and then advanced breeding lines were thoroughly tested and compared to standards in representative environments across several locations in the Midwestern region in Brazil. As a result, we developed an early-soybean with cycle-length of 107 days; usually cycles range from 90 to 160 days. It presents desirable traits as high yield ( $3677 \mathrm{~kg} \mathrm{ha}^{-1}$ ), Brazilian national average ranged between 2.5 and 3 thousand $\mathrm{kg} \mathrm{ha}^{-1}$; broad adaptability, with $19 \%$ of oil, and $38.4 \%$ of protein on the seeds. Oil and protein standard contents are $20 \%$ and $40 \%$, respectively. In addition, it is root-knot nematode (Pratylenchus brachyurus) resistance, not differing statistically (RF = 1.70) from the expected value given by Crotalaria spectabilis ( $R F=1.14$ ). Accordingly, we recommend this new cultivar to producers that intend to grow a second crop of either corn or cotton in the summer, or for crop producing areas with high incidence of $P$. brachyurus.
\end{abstract}

Index terms: Plant breeding; disease resistance; Glycine Max; Pratylenchus brachyurus.

\section{RESUMO}

No Brasil, as perdas causadas pelos nematoides aumentaram nas áreas produtoras à medida que a cultura da soja se expande. Portanto, este trabalho teve como objetivo desenvolver uma nova cultivar de soja não geneticamente modificada que combinasse características como resistência a nematoides, maturação precoce, alta produtividade de grãos e altos teores de óleo e proteína. Assim, sementes (F2) derivado do duplo cruzamento entre (Guarani x Sambaiba) x (M Soy 6101 x Conquista) foram utilizadas para a formação da geração F3. As gerações seguintes foram avançadas pelo método SSD até F6, onde plantas mostrando características superiores foram separadamente cultivadas para testes de progênie. Em seguida, as linhas de reprodução avançadas foram exaustivamente testadas e comparadas a cultivares padrões em vários locais da região Centro-Oeste do Brasil. Como resultado, desenvolvemos uma soja precoce com ciclo anual de 107 dias; geralmente, os ciclos variam de 90 a 160 dias. Essa nova cultivar apresenta características desejáveis como alta produtividade (3677 $\left.\mathrm{kg} \mathrm{ha}^{-1}\right)$, onde a média nacional brasileira varia entre 2,5 e 3 mil kg ha-1. Também apresenta, ampla adaptabilidade e $19 \%$ de óleo e 38,4\% de proteína nas sementes. Teores padrão de óleo e proteína são 20\% e 40\%, respectivamente. Além disso, montra resistência ao nematoide-de-galhas (Pratylenchus brachyurus), não diferindo estatisticamente ( $F R=1,70)$ do valor esperado dado pela Crotalaria ( $R F=1,14)$. Assim, recomendamos esta nova cultivar para produtores que pretendam cultivar uma segunda safra de milho ou algodão no verão, ou para áreas produtoras de culturas com alta incidência de $P$. brachyurus.

Termos para indexação: Melhoramento de plantas; resistência a doenças; Glicina Max; Pratylenchus brachyurus. 


\section{INTRODUCTION}

Further growth in world crop production will be accomplished mostly by increasing yield; the global cereal area is expected to grow only marginally, while an expansion on soybean area is projected to satisfy animal feed and vegetable oil demands. Although soybean seeds are mainly used as a supplement in feed rations for livestock; such as poultry and swine, and recently also in aquaculture; its industrial uses range from the production of yeasts and antibodies to manufacture of soaps and disinfectants. Concerning human consumption, this is mainly used as purified oil, in margarine, shortenings, cooking and salad oils. Also, protein meals are dominated by soybean meal, which accounts for more than two-thirds of global protein meal production. In the global scenario, Brazil is projected to overtake the United States as the largest soybean producer. Brazilian soybean production is prospected to grow at $2.6 \%$ per annum (p.a.), the fastest of the major producers as more additional land is available, compared to Argentina (2.1\% p.a.) and the United States (1.0\% p.a.) (OECD/FAO, 2017; Rüdelsheim; Smets, 2012).

Soybean genetic improvement has been critical for the success of this crop in Brazil and the increases in the yield over the past 20 years have made of soybean the main Brazilian crop (CONAB, 2017). However, despite its high yield genetic potential, significant decreases in Brazilian soybean productivity have been observed mainly due to biotic and abiotic stresses combinations.

Productivity losses caused by nematodes have increased as the soybean culture quickly expands mainly in sandy and low-fertility soils (Kath et al., 2017). Brazilian nematodes species most damaging to soybean are Meloidogyne javanica, Meloidogyne incognita, Heterodera glycines, Pratylenchus brachyurus, Rotylenchulus reniformis and (Santana et al., 2009; Dias et al., 2010; Furlanetto et al., 2010).

In this context, $P$. brachyurus occurrence has gained importance whatever because of damage caused to soybean crops or for its broad dispersion and high incidence in producing areas, such as Cerrado. The surveys of the population of nematodes in the north of Mato Grosso, harvest 2016/2017 and second crop 2017, found an increase in the incidence of root lesions nematodes in all the municipalities studied; all of 3328 samples analyzed were found to be positive for the presence of Pratylenchus sp. (Maba et al., 2017).

Many soybean producers have been looking for improved yields and profitability by planting early-maturing soybean cultivars to reduce $P$. brachyurus populations. The use of $C$. spectabilis in succession or rotation with soybean has been the most effective measure for the control of rootknot and root-lesion nematodes in infested areas (McSorley et al., 2009; Wang; Sipes; Schmitt, 2002). Besides, planting early-maturing soybean during the soybean off-season, allows the summer corn to be cultivated from January to April in the Brazilian Center-South region.

Considering soybean farmers demand, our goal with this study was to develop a new soybean cultivar belonging to the early-maturity group, P. brachyurus resistant with higher seed yield, and high oil and protein contents. As a result, we developed a new cultivar that presents comparative advantages over others in high productivity and $P$. brachyurus resistance.

\section{MATERIAL AND METHODS}

Soybean lineages were derived from the doublecrossing between (Guarani x Sambaiba) x (M Soy 6101 $\mathrm{x}$ Conquista) on the experimental station of the Federal University of Uberlândia, Latitude $18^{\circ}$ 52' 94" S, Longitude $48^{\circ} 20^{\prime} 45^{\prime \prime} \mathrm{O}$, altitude $835 \mathrm{~m}, \mathrm{MG}$, Brazil. Generations were advanced by the single seed descent (SSD) method of breeding according to Silva et al., 2017. Therefore, we have collected one single seed from each one of the F2 plants, advanced generations by the SSD method (Table 1) until F6, and then, selected seeds from single plants showing superior characteristics. F6 seeds were grown separately to perform the progeny tests in a randomized block design, with three replications. These tests were conducted across many locations over 2 years, and promising advanced breeding lines were thoroughly compared to appropriate cultivar standards in representative environments across several locations in the states of Minas Gerais (MG), Goiás (GO) Mato Grosso (MT) and São Paulo (SP).

The selection of desired traits through generations were carried out on features as seed yield, lodging resistance, emergence, disease tolerance, maturity, plant height, and other visual characters. A previous study revealed a complex relationship between grain yield, plant height, and maturity, but indicated that breeding of adapted and high-yielding varieties is feasible (Kurasch et al., 2017).

Cultivar selection aiming at $P$. brachyurus resistance were carried out at the Association of Mato Grosso State Seed Producers (APROSMAT) greenhouses, from November 2013 to January 2014. Twelve soybean lineages of the Federal University of Uberlandia were selected for evaluation, BRS MT Pintado was set as control and antagonist plant, Crotalaria spectabilis, as the parameter of resistance. The inoculum was multiplied in okra in greenhouse conditions, and then extracted from the roots by the method proposed by Coolen and D 'Herde (1972). 
Table 1: Breeding procedures applied on soybean developing, preliminary and standard yield trials.

\begin{tabular}{|c|c|c|c|c|}
\hline Generation & Year & Location & aMethod & Selected features \\
\hline $\mathrm{F}_{1}$ & 2004 & \multirow{8}{*}{$\begin{array}{l}\text { Capim Branco farm } \\
\text { Uberlândia, MG }\end{array}$} & double-cross & $\begin{array}{l}\text { Diseases resistance } \\
\text { and grain yield }\end{array}$ \\
\hline $\mathrm{F}_{2 / 3}$ & 2005 & & SSD & \multirow{4}{*}{ Diseases resistance } \\
\hline $\mathrm{F}_{4}$ & 2006 & & SSD & \\
\hline $\mathrm{F}_{5}$ & 2006 & & SSD & \\
\hline $\mathrm{F}_{6}$ & 2007 & & SSD & \\
\hline $\mathrm{F}_{7}$ & 2007 & & Progeny-test & \multirow[t]{3}{*}{$\begin{array}{l}\text { Diseases resistance } \\
\text { and grain yield }\end{array}$} \\
\hline $\mathrm{F}_{8}$ & 2008 & & Preliminary yield assay & \\
\hline $\mathrm{F}_{9}$ & $2008 / 9$ & & $\begin{array}{c}\text { Intermediate yield } \\
\text { assay }\end{array}$ & \\
\hline$F_{10 / 11}$ & $\begin{array}{l}2009 / 10 \\
2010 / 11\end{array}$ & $\begin{array}{l}\text { Uberlândia-MG; Alto Taquari- } \\
\text { MT; Campo Alegre, Goiatuba, } \\
\text { Palmeiras de Goiás-GO }\end{array}$ & Final yield assay & \multirow[t]{2}{*}{$\begin{array}{c}\text { Diseases resistance and } \\
\text { quantitative traits }\end{array}$} \\
\hline$F_{11 / 12}$ & $\begin{array}{l}2011 / 12 \\
2012 / 13\end{array}$ & $\begin{array}{l}\text { Several localities in } \\
\text { MG, GO, MT, SP }\end{array}$ & VCU & \\
\hline
\end{tabular}

MG = Minas Gerais; GO = Goiás; MT = Mato Grosso; SP = São Paulo; VCU = value for cultivation and use; aSSD = single seed descent method.

The damage and reproductive potentials of $P$. Brachyurus populations on soybean were assessed by the reproduction factor $(\mathrm{RF})$. This measure has been widely used in nematological studies to define resistance and susceptibility of plants to nematodes. According to Taylor and Sasser (1978), since reproductive ability on a given host is directly related to resistance nematode reproduction that can be used to measure root-knot nematode resistance. The $\mathrm{RF}$ is obtained by the ratio $\mathrm{R}$ = final nematode population/initial nematode population, where $\mathrm{R} \leq 1$ indicates an inefficient host (Oostenbrink, 1966).

The analysis of variance (ANOVA) was used to test the differences between RF means. The null hypothesis states there was no difference between the observed values and the expected that is value given by Crotalaria spectabilis, which is a poor-host of Pratylenchus spp. The RF means were grouped by Scott-Knott at $5 \%$ of probability level to compare treatment means whenever the situation led to a significant F-test (Jelihovschi; Faria; Allaman, 2014).

Value for Cultivation and Use (VCU) assays were carried out on a randomized blocks design with three replicates, from 2011 to 2013. Plot sizes were equal to $5.0 \mathrm{~m}^{2}$. We have labeled the experimental by regions with numbers. Ituverava in São Paulo (SP) was identified as Region 302 whereas; Region 303 was set by Uberlândia, Urutaí and Itumbiara cities, in Minas Gerais (MG). Rondonopolis set region 401, Alto Taquari and Palmeiras de Goiás, in Goiás (GO); Region 402, by Lucas Rio Verde and Sinop, in Mato Grosso (MT); and Region 403 was set by Porto Alegre do Norte, also in MT.

In addition, the reaction to the main soybean diseases was also assessed in greenhouse and field during 2012 -2013 seasons as minimum requirements for determination of the Value of Cult and Use of Soy (Glycine max). For registration in the National Register of Cultivars (RNC), diseases and nematodes reactions were measured according the codes established in Item III-C, of the ANEXO VI provide by the Ministry of Agriculture, Livestock and Supply (MAPA, 2011) as shown in Table 2.

Table 2: Ministry of Agriculture, Livestock and Supply codes and concepts for evaluation of soybean reaction to diseases and nematodes.

\begin{tabular}{cc}
\hline Code & Concept \\
\hline R & Resistant \\
MR & Moderately tough \\
MS & Moderately susceptible \\
S & Susceptible \\
AS & Highly susceptible \\
T & Tolerant \\
MT & Moderately tolerant \\
SI & No information \\
\hline
\end{tabular}


The diseases incidence were evaluated by visual inspection. The symptoms were evaluated in practically the whole aerial part of the plant, like stems, pods, seeds and mainly leaves.

Distinctness, uniformity and stability (DUS) experiments were conducted from 2010 to 2012 under conditions ensuring normal development of plants on the Capim Branco farm. Each assay included 300 plants with three replicates.

The descriptors hypocotyl color, type of growth, pubescence color, flower color, pod color, the shape of the seed, integument color, and peroxidase reaction were also assessed. As well as the agronomic traits, the number of days to the flowering, the plant height at flowering, the number of days to maturity, the plant height at maturity, the first pod height, the number of nodes on the main stem at maturity, the number of pods with one, two and three seeds per plant, the total number of pods per plant, the number of seeds per pod, and grain yield.

We computed the number of days from the emergence to maturation when $95 \%$ of the pods were dried; the maturity was reported as the first day on which $95 \%$ of the pods turned brown. First pod insertion was calculated as a measure from the soil level to the insertion of the first pod. We have assessed pod dehiscence using a scale ranging from 0 (no dehiscence) to 10 (complete dehiscence); and lodging resistance from 1 (no lodging) to 5 (all plants are prostrate) (Fehr, 1987). To evaluate the productivity of cultivars and lineages, we have assessed yielding per useful plots area; standardized to $13 \%$ of humidity and transformed into kilograms per hectare (Silva et al., 2017).

\section{RESULTS AND DISCUSSION}

UFUS 7401 stood out among all lineages tested by combining desirable traits as early-maturity, high seed yielding, and high oil and protein contents. As minimum requirements for determination of the Value of Cult and Use of Soy, on the tests performed during 2012 -2013 seasons UFUS 7401did not present symptoms of the main soybean diseases (Table 3). The frogeye spot can appear at almost any stage of culture; however, the highest incidence is generally observed of the R1 stage. The leaves symptoms are circular spots, with dark halo and light brown center. Regarding, the Phytophthora root rot, its symptoms can be observed from the emergency causing the premature death of the seedlings, until the adult plants, in the form of an aqueous rot that begins at the base of the stem and evolves into the branches up to the middle third of the main stem.
Table 3: UFUS 7401 reaction to diseases results of evaluation performed on Value for Cultivation and Use (VCU) assays, from 2011 to 2013.

\begin{tabular}{ccc}
\hline Reaction & Greenhouse & Field \\
\hline Bacterial pustule & $\mathrm{R}$ & $\mathrm{R}$ \\
Bacterial blight & $\mathrm{R}$ & $\mathrm{R}$ \\
Frogeye leaf spot & $\mathrm{R}$ & $\mathrm{R}$ \\
Phytophthora root rot & $\mathrm{R}$ & $\mathrm{R}$ \\
Soybean Mosaic Virus & $\mathrm{R}$ & $\mathrm{R}$ \\
Powdery mildew & $\mathrm{R}$ & $\mathrm{R}$ \\
Stem canker & $\mathrm{R}$ & $\mathrm{R}$ \\
Sudden Death Syndrome & $\mathrm{R}$ & $\mathrm{R}$ \\
\hline
\end{tabular}

$\mathrm{R}=$ Resistant

Susceptible genotypes to the Soybean Mosaic Virus present seeds with spots of brown or black color, according to the color of the thread. Concerning the Stem canker, the symptoms can be observed in the form of necrosis in the cotyledons. In developed crops, it causes the strangulation of the petioles and shaded branches and necrosis of petioles, canker in the veins and peduncle of the leaves, cancer in the stems, cancer in the pods and precocious defoliation. When the infection occurs in pods in the R3-R4 phase, those acquire a dark brown or black color, becoming twisted and without the formation of grains. In the pods, the lesions initially have clear streaks or patches of rounded shape, which develop into black spots.

The Bacterial blight symptoms may occur less clearly in the petioles, stems, and pods, but are more noticeable in the leaves, starting with small lesions surrounded by a yellowish halo with translucent in appearance. When it evolves become necrotic and of angular contour limited by the secondary veins. The nearby lesions coalesce and form large patches, which may be torn.

The Bacterial pustule early symptoms consists of small light green spots on leaves in the mid to upper canopy. As the disease progresses, little brown color pustules start growing on the middle of the green spots, turn that into yellow. The Sudden Death Syndrome (SDS) symptoms consist of light green to chlorotic (yellow) patches that progress to chlorosis, and vein necrosis. As the disease progresses, trifoliate leaves detach from the petioles and fall.

Although, we have not found UFUS 7401 resistant to nematodes Meloidogyne incognita, Meloidogyne javanica, it was found resistant to P. brachyurus showing no significant difference from C. spectabilis (Table 4). 
The results are particular promising to farmers, as $P$. brachyurus has become increasingly common in soybean fields the losses caused by nematodes have also increased as they change and damage the root system of their hosts, impair water and nutrient absorption and translocation, and reduce root development and vegetative growth (Kath et al., 2017). Lima et al. (2015) have assessed P. brachyurus populations throughout Tocantins (BR) in soybean field grown off-season and found this pathogen present in $82 \%$ of samples with densities ranging from 23 to 20,400 nematodes per $200 \mathrm{~cm}^{3}$ soil, or $10 \mathrm{~g}$ root samples.

Table 4: Reproduction factor (RF) of soybean varieties assessed to Pratylenchus brachyurus (2013 - 2014). Association of Mato Grosso State Seed Producers (APROSMAT), Mato Grosso, Brazil.

\begin{tabular}{cc}
\hline Varieties & aReproductive Factor \\
\hline Crotalaria & $1.14 \mathrm{a}$ \\
UFUS 7401 & $1.70 \mathrm{a}$ \\
Tapajós & $2.56 \mathrm{a}$ \\
UFUS37 & $2.84 \mathrm{a}$ \\
Guará & $3.50 \mathrm{a}$ \\
UFUS32 & $3.56 \mathrm{a}$ \\
119HM & $3.68 \mathrm{a}$ \\
Pintado & $3.70 \mathrm{a}$ \\
Vila Rica & $5.02 \mathrm{a}$ \\
Conquista & $6.98 \mathrm{~b}$ \\
105 UDI & $7.16 \mathrm{~b}$ \\
Mineira & $11.70 \mathrm{c}$ \\
Carajás & $12.78 \mathrm{c}$ \\
CV (\%) & 25.80 \\
\hline
\end{tabular}

${ }^{a}$ Averages followed by same letter constitute a homogeneous group by the Scott Knott test at $5 \%$ probability.
The past decade has seen substantial progress in our knowledge of microorganisms and push-pull plants (e.g., C. spectabilis) that contribute to the biocontrol of nematodes (Anene; Declerck, 2016). According to Monteiro (1993), despite Crotalaria species are generally unfavorable or poorly adapted to the reproduction of Pratylenchus spp. there may be breeds or nematode populations that can multiply or remain in these plants; as these reactions vary according to species and their populations, both plants and parasites this might explain our Crotalaria RF results superior to one.

Besides, UFUS 7401 is an early-soybean cultivar since its life cycle-length is 107 days average, which allows farmers to grow a second crop per year rather than one. Usually the annual cycle range from 90 to 160 days until the harvest of grains, depending on the cultivar and the sowing season (Wutke et al., 2007). UFUS 7401 has shown lodging resistance, it presents semi-determined stem growth and is resistant to pod dehiscence (Table 5). It presents green hypocotyl, light brown pubescence, light brown pod, white flowers, flattened spherical seed shape, yellow tegument, black hilum, and positive peroxidase reaction.

Compared with shade susceptible varieties there were no UFUS 7401 lodged plants in our experiments. Lodging is a severe problem that results in reduced grain crop yield. Liu et al. (2016) show that shading inhibits the transportation and degradation of sucrose into cellulose in the soybean stem. Lower cellulose content leads to a higher rate of lodging at the seedling stage of soybean in maizesoybean intercropping. High sucrose phosphate synthase and sucrose synthase activities in the stem stimulate shade tolerance and lodging resistance traits, which ensures stem physical strength and reduces the lodging rate.

Excessive vegetative growth might lead to lodging, which reduces yields by causing increased harvest losses and inefficient use of sunlight by the plant. Lodging percentage have shown significant negative correlations with grain

Table 5: Average results of the agronomic traits assessed on Value for Cultivation and Use (VCU), and Distinctness, uniformity and stability (DUS) assays, from 2011 to 2013.

\begin{tabular}{|c|c|c|c|c|c|c|c|}
\hline \multirow{2}{*}{${ }^{a}$ Region } & \multicolumn{2}{|c|}{ Cycle (days) } & \multirow{2}{*}{$\begin{array}{l}\text { Plant height } \\
\text { (cm) }\end{array}$} & \multirow{2}{*}{$\begin{array}{l}\text { First pod } \\
\text { height }(\mathrm{cm})\end{array}$} & \multirow{2}{*}{ Lodging } & \multirow{2}{*}{ Dehiscence (\%) } & \multirow{2}{*}{$\begin{array}{c}\text { 100-seec } \\
\text { weight }\end{array}$} \\
\hline & Flowering & Total & & & & & \\
\hline 401 & 42 & 105 & 67 & 10 & 1 & 0 & 15 \\
\hline 402 & 41 & 110 & 68 & 10 & 1 & 0 & 16 \\
\hline 403 & 38 & 105 & 67 & 10 & 1 & 0 & 15 \\
\hline 302 & 46 & 108 & 70 & 11 & 1 & 0 & 14 \\
\hline
\end{tabular}

${ }^{\text {aRegion }} 302$ = Ituverava; Region 303 = Uberlândia; Urutaí, Itumbiara; Region 401 = Rondonopolis, Alto Taquari, Palmeiras de Goiás; Region 402 = Lucas Rio Verde, Sinop; Region 403 = Porto Alegre do Norte. 
yield (Buzzello et al., 2013), root weight, stem diameter, and stem strength (Chen et al., 2017); and significant positive correlations with branch number, internode length, number of nodes, and plant height (Chen et al., 2017; Lee et al., 2015).

The UFUS 7401 resistance to pod dehiscence allows this new cultivar to approach its yield potential. Pod dehiscence (shattering) is a significant source of yield loss in the mechanically harvested soybean. Harvesting shattering-susceptible soybean varieties in dry weather conditions can lead to seed losses of 50 to $100 \%$ (Bhor; Chimote; Deshmukh, 2014).

As an early-soybean cultivar, UFUS 7401 allows farmers to grow a second crop per year rather than one. As soybean is a photoperiod-sensitive and self-pollinated species, days to flowering and maturity, duration of flowering-to-maturity and plant height are crucial for soybean adaptability and yield (Zhang et al., 2015). In Central Brazil, early soybean varieties allow farmers to grow a second crop either of corn or cotton in the summer, to optimize the use of machinery and the available workforce, resulting in increased profit for the farmer (Dias et al., 2016). This practice reduces risks of yield losses due to pests and environmental stresses by keeping soybean on the field for a shorter period, which minimizes crop exposure to insect and disease. In Brazil, the maize (Zea mays L.) is usually a good option as a second crop sown in February/March in a total area of 9.9 million hectares (CONAB, 2016).

UFUS 7401 have exhibited average yield (3677 $\mathrm{kg} \mathrm{ha}^{-1}$ ) above both Brazilian national average yield. Excluding the 2016/17 harvest results, the soybean Brazilian yielding national average ranged between 2.5 and 3 thousand $\mathrm{kg} \mathrm{ha}^{-1}$ over the last ten years (CONAB, 2017). UFUS 7401 also have exhibited average yield above other soybean cultivar standards (Table 6). As shown in Table 7, we have found UFUS 7401 oil content percentages ranging from 19 to $20 \%$, and protein content from 37 to $39 \%$.

Table 6: Comparison of averaged yielding between UFUS 7401 and standard cultivars assessed on Value for Cultivation and Use (VCU) assays, from 2011 to 2013.

\begin{tabular}{|c|c|c|c|c|c|}
\hline \multirow{3}{*}{${ }^{\text {aRegion }}$} & \multicolumn{4}{|c|}{ Yield (kg ha-1) } & \multirow{3}{*}{ CV (\%) } \\
\hline & \multirow{2}{*}{ UFUS 7401} & \multicolumn{3}{|c|}{ Witnesses } & \\
\hline & & BRS 752S & MSOY 7211 & Emgopa 315 & \\
\hline 401 & 3755 & 3600 & 3550 & 3750 & 12 \\
\hline 402 & 3650 & 3500 & 3650 & 3600 & 11 \\
\hline 403 & 3580 & 3660 & 3340 & 3650 & 12 \\
\hline 302 & 3800 & 3250 & 3330 & 3150 & 11 \\
\hline 303 & 3600 & 3350 & 3250 & 2970 & 11 \\
\hline Average & 3677 & 3472 & 3424 & 3424 & \\
\hline
\end{tabular}

aRegion 302 = Ituverava; Region 303 = Uberlândia; Urutaí, Itumbiara; Region 401 = Rondonopolis, Alto Taquari, Palmeiras de Goiás; Region 402 = Lucas Rio Verde, Sinop; Region 403 = Porto Alegre do Norte. CV = Coefficient of variation.

Table 7: Comparison of averaged percentage of oil and protein yielding content between UFUS 7401 and standard cultivars assessed on Value for Cultivation and Use (VCU) assays, from 2011 to 2013.

\begin{tabular}{|c|c|c|c|c|c|c|c|c|}
\hline \multirow{3}{*}{ Region } & \multirow{3}{*}{$\begin{array}{c}\text { UFUS } 7401 \\
\text { Oil }\end{array}$} & \multicolumn{7}{|c|}{ Witnesses } \\
\hline & & \multicolumn{2}{|c|}{ A } & \multicolumn{2}{|c|}{ B } & \multicolumn{2}{|c|}{ C } & \multirow[b]{2}{*}{ Protein } \\
\hline & & Protein & Oil & Protein & Oil & Protein & Oil & \\
\hline 401 & 19 & 38 & 19 & 38 & 17 & 39 & 18 & 37 \\
\hline 402 & 18 & 39 & 18 & 38 & 19 & 38 & 19 & 39 \\
\hline 403 & 19 & 39 & 19 & 39 & 19 & 39 & 19 & 38 \\
\hline 303 & 20 & 37 & 19 & 38 & 19 & 39 & - & - \\
\hline 302 & 19 & 39 & 18 & 37 & 19 & 39 & - & - \\
\hline
\end{tabular}

(-) Missing data; Region 302 = Ituverava; Region 303 = Uberlândia; Urutaí, Itumbiara; Region 401 = Rondonopolis, Alto Taquari, Palmeiras de Goiás; Region 402 = Lucas Rio Verde, Sinop; Region 403 = Porto Alegre do Norte. 
The soybean is one of the world's most important crops mainly because of its high protein and oils contents on the seeds, which are usually $40 \%$ and $20 \%$, respectively (Singh; Nelson; Chung, 2007).

Besides the primary objective of soybean, breeding program is the generation of ever higher yielding soybean cultivars, plant breeders also want to improve seed constituent value, which is mainly protein and oil (Phansak et al., 2016). However, seed protein and oil concentration are quantitative traits, which are determined by the interaction among many genes with small to moderate genetic effects and their interaction with the environment (Hwang et al., 2014); and the amount of oil and proteins of soybean grains can vary according to the environment (Bianculli et al., 2016) and genotype. Furthermore, longterm selection for higher yield has also depressed protein and elevated oil (Rincker et al., 2014).

\section{CONCLUSIONS}

UFUS 7401 is distinct from any other soybean cultivar, homogeneous to the descriptors that had identified it, and it is, as well, stable through successive generations and was included in the Brazilian National Register of Cultivars, register number 33897 . UFUS 7401 is ideal for farmers that intend to grow a second crop of either corn or cotton in the summer, or for crop producing areas with a high incidence of $P$. brachyurus. Its ideal population density range from 270 to 300 thousand plants per hectare.

\section{REFERENCES}

ANENE A.; DECLERCK, S. Combination of Crotalaria spectabilis with Rhizophagus irregularis MUCL41833 decreases the impact of Radopholus similis in banana. Applied Soil Ecology, 106:11-17, 2016.

BIANCULLI, M. L. et al. Contribution of incident solar radiation on leaves and pods to soybean seed weight and composition. European Journal of Agronomy, 77:1-9, 2016.

BHOR, T. J.; CHIMOTE V. P.; DESHMUKH M. P. Inheritance of pod shattering in soybean [Glycine max (L.) Merrill]. Electronic Journal of Plant Breeding, 5(4):671-676, 2014.

BUZZELLO, G. L. et al. Ação de inibidores de auxina sobre o desenvolvimento e rendimento de plantas de soja. Revista Ceres, 60(5):621-628, 2013.

CHEN, H. et al. Combining QTL and candidate gene analysis with phenotypic model to unravel the relationship between lodging and related traits in soybean. Molecular Breeding, 37(43): 1-14, 2017.
CONAB - Companhia Nacional de Abastecimento. Acompanhamento da safra brasileira de grãos, v. 5 Safra 2017/18 - Segundo levantamento, Brasília, p.1-120, 2017. Available in: <http://www.conab.gov.br/conteudos. php?a=1253>. Access in: September 12, 2017.

CONAB. Companhia Nacional de Abastecimento. Acompanhamento da safra brasileira de grãos, safra 2015/16 - Nono levantamento, Brasília, p.1-178, 2016. Available in: <http://www.conab.gov.br/conteudos. php?a=1253>. Access in: June 02, 2018.

COOLEN, W. A.; D'HERDE, C. J. A method for the quantitative extraction of nematodes from plant tissue. Ghent: State Nematology and Entomology Research Station, Merelbeke, BEL: State Agricultural Research Centre, 1972, 77p.

DIAS, V. P. et al. Resistance to Meloidogyne incognita, Meloidogyne javanica, and Pratylenchus brachyurus in sunflower cultivars adapted to the tropical region of Brazil. Tropical Plant Pathology, 41(5):325-330, 2016.

DIAS, W. P. et al. Nematoides em Soja: Identificação e controle. Londrina, PR: Embrapa Soja, Circular Técnica, v.76, 2010, 7p.

FURLANETTO, C. et al. Desenvolvimento das culturas de soja, milho e trigo cultivadas em áreas infestadas com o nematoide Tubixaba tuxaua no Oeste do Paraná. Tropical Plant Pathology, 35(5):295-302, 2010.

FEHR, W. R. Breeding methods for cultivar development. In: WILCOX, J. R. (Ed.), Soybeans: Improvement, production, and uses. (2 ${ }^{\text {nd }}$ ed.). 1987. Agronomy Monograph 16, p.249293. ASA, CSSA, and SSSA, Madison.

HWANG, E. Y. et al. A genome-wide association study of seed protein and oil content in soybean. BMC Genomics, 15(1):1-12 2014.

KATH, J. et al. Control of Pratylenchus brachyurus in soybean with Trichoderma spp. and resistance inducers. Journal of Phytopatholgy, 165:791-799, 2017.

KURASCH, A. K. V. et al. Phenotypic analysis of major agronomic traits in 1008 RILs from a diallel of early European soybean varieties. Crop Science, 57(2):726-738, 2017.

JELIHOVSCHI, E. G.; FARIA, J. C.; ALLAMAN, I. B. Scottknott: A package for performing the Scott-Knott clustering algorithm in R. Tema, 15(1):3-17, 2014.

LEE, S. et al. SNP markers linked to QTL conditioning plant height, lodging, and maturity in soybean. Euphytica, 203(3):521-532, 2015. 
LIMA, F. S. O. et al. Population dynamics of the root lesion nematode, Pratylenchus brachyurus, in soybean fields in Tocantins state and its effect to soybean yield. Nematropica, 45(2): 170-177, 2015.

LIU, W. et al. Relationship between cellulose accumulation and lodging resistance in the stem of relay intercropped soybean [Glycine max (L.) Merr.]. Field Crops Research, 196:261-267, 2016.

MABA, T. S. M. et al. Levantamento populacional de gêneros de nematoides na região do médio norte de mato grosso, safra 2016/2017 e segunda safra 2017. Fundação Rio Verde, Boletim Técnico n. 06, 2017, 5p. Available in: <file:///C:/Users/ Carolina/Downloads/2017\%20E\%20SEGUNDA\%20SAFRA\%20 2017\%20\%20(1).pdf>. Access in: December 11, 2017.

MAPA. Ministério da agricultura, pecuária e abastecimento. Proteção de Cultivares no Brasil. Secretaria de Desenvolvimento Agropecuário e Cooperativismo, Brasília: Mapa/ACS, 202p., 2011. Available in: <http://www. agricultura.gov.br>. Access in: December 11, 2017

MCSORLEY, R. et al. Non-target effects of sun hemp and marigold cover crops on the soil invertebrate community. Nematropica, 39(2):235-245, 2009.

MONTEIRO, A. R. Controle de nematóides por espécies de adubos verdes. In: WUTKE, E. B.; BULISANI, E. A.; MASCARENHAS, H. A. A. (Eds.), I Curso sobre adubação verde no Instituto Agronômico, Campinas: Instituto Agronômico, Documentos IAC, 35, p.109-121, 1993.

OECD/FAO. OECD-FAO. Agricultural Outlook 2017-2026. OECD Publishing, Paris: 2017, 144p. Available in: <https:// www.oecd-ilibrary.org/agriculture-and-food/oecd-faoagricultural-outlook-2017-2026_agr_outlook-2017-en> Access in: December 11, 2017.

OOSTENBRINK, M. Major characteristics of the relation between nematodes and plants. Mededelingen van de, 66:1-46, 1966.

PHANSAK, P. et al. Multi-population selective genotyping to identify soybean [Glycine max (L.) Merr.] seed protein and oil QTLs. G3, 6(6):1635-1648, 2016.
RINCKER, K. et al. Genetic improvement of U.S. soybean in maturity groups II, III, and IV. Crop Science, 54:1-14, 2014.

RÜDELSHEIM, P. L. J.; SMETS, G. Baseline information on agricultural practices in the EU Soybean (Glycine max (L.) Merr.). EuropaBio AISBL, Brussels, 43p. 2012.

SANTANA, H. P. E. et al. Variabilidade genética em populações de campo do nematoide de cisto da soja provenientes dos estados do Paraná e Rio Grande do Sul. Tropical Plant Pathology, 34(4):261-264, 2009.

SILVA, F. L. da. et al. Methods for advancing segregating populations. In: SILVA, L. F. da. et al. Soybean Breeding, Cham, ZG: Springer, 2017. p.149-169.

SINGH, R. J.; NELSON R. L.; CHUNG G. H. Soybean (Glycine $\max (\mathrm{L}$.$) Merr.). In: SINGH, R. J. (Ed.), Genetic resources,$ chromosome engineering, and crop improvement volume 4 oilseed crops, CRC Press, Boca Raton, 2007. p.3-50.

TAYLOR, A. L.; SASSER, J. N. Biology, identification and control of root-knot nematodes (Meloidogyne spp.). Department of Plant Pathology, North Carolina State University and the United States Agency for International Development. Printed by North Carolina State University Graphics, 1978. 110p. Available in: <http://pdf.usaid.gov/pdf_docs/ PNAAK809.pdf>. Access in: January 12, 2018.

WANG, K. H.; SIPES, B. S.; SCHMITT, D. P. Crotalaria as a cover crop for nematode management: A review. Nematropica, 32(1):35-57, 2002.

WUTKE, E. B. et al. Bancos comunitários de sementes de adubos verdes: Informações técnicas et al. Brasília: Ministério da Agricultura, Pecuária e Abastecimento, 2007, 56p. Available in: <file://C:/Users/Carolina/Downloads/Bancos\%20 comunit\%C3\%A1 rios\%20de\%20sementes $\% 20$ de $\% 20$ adubos\%20verdes_\%20informa\%C3\%A7\%C3\%B5es\%20 t\%C3\%A9cnicas.pdf> Access in: January 12, 2018.

ZHANG, J. et al. Genome-wide association study for flowering time, maturity dates and plant height in early maturing soybean (Glycine max) germplasm. BMC Genomics, 16(217):1-11, 2015. 